selves on page 76 of the above-mentioned revision, that styx may prove to be only a melanic form of plagiata, I have no cause to feel ashamed of my record. It may be as well here to mention that B. \& McD. have pronounced Acyphas plagiata Walk. to be Hemerocampa definita Pack, and not leucostigma A. \&. S., as I at first thought. (Contr. II, No. 5, p. 203, Aug. 1914).

PLATYPTERYGIDÆ.

683. Eudeilinea herminiata Gn.--Dorothy, July 5th, 1905. One specimen.

\title{
OCCURRENCE OF EUMERUS (SYRPHIDÆ) IN CALIFORNIA.
}

BY W. M. DAVIDSON, U. S. BUREAU OF ENTOMOLOGY, WASHINGTON, D. C.

The large Syrphid genus Eumerus Meigen is well distributed over the lands of the Eastern Hemisphere, occurring from Britain to Australia. In the Americas there appear to be no indigenous species, but the onion fly (Eumerus strigatus Fallen) has been bred from Iris and Amaryllis bulbs in North America. Felt* records that it was reared in New York State from Iris roots found at Saratoga Springs, N. Y., August, 1911. He also states that it has been recorded from Buffalo, N. Y., Connecticut and Brownsville, Texas. During the summer of $1914 \mathrm{I}$ was surprised to find an Eumerus on the wing in central California. Ten specimens, of which 8 were males, were secured, the dates and numbers taken being as follows: 1 male at Walnut Creek, Cal., May 25; 1 male at Berkeley, Cal., June 12; 6 males and 2 females at Oakland, Cal., July 26. At Berkeley a few others were observed and at Oakland many more. At both places the flies occurred in gardens flying close to the ground and making short darting flights among the vegetation, thereby reminding one of some of the smaller bees. Professor Bezzi of Turin, Italy, to whom I sent a male, pronounced the specimen very similar to the European E. tuberculatus Rondani, which he states is perhaps only a variety of p. 119 .

*Felt, New York State Museum, Report of the State Entomologist, 1911; 
strigatus Fallen. Mr. F. Knab, of the U. S. National Museum, has pronounced the specimens I submitted to him strigatus. It would appear that this European insect has a wide distribution over the United States since it has been taken in the East, South and West. Its habits on the wing are rather similar to those of Paragus tibialis Fallen, a common species that superficially resembles the Eumerus.

\section{FIELD NOTES AND QUESTIONS.}

The Occurkence of Mantis religiosa L. in Canada.

Four specimens of the European Praying Mantis (Mantis religiosa L.), taken in Ontario, have been seen by the writer since September, 1914. Three of these were captured in Prince Edward County during the past two seasons, while the fourth was taken some years ago near Simcoe, Norfolk Co. The latter specimen was sent to me for determination by the Rev. Prof. C. J. S. Bethune.

Of the three specimens from Prince Edward County one was taken last year near Picton, and is now in the collection of the Picton Collegiate Institute; a second was taken at Green Point, Sophiasburg Township, about Aug. 15, by Mr. Hugh W. Clark, Assistant Representative of the Dept. of Agriculture, Picton; while the third comes from Carrying Place, and is in the International Collection of Canadian Insects, Ottawa. It was taken by Mr. J. H. Herrington on Oct. 10, 1914.-E. M. W.

Referring to Mr. Bethune's remarks in the January number on "Caterpillars as Weather Prophets," according to Brez in "Flores des Insectophiles, Notes suppl. p. 134," "when a spider spins a long thread, there is a certainty of fine weather for at least ten or twelve days afterward." Of this Kirby had the following to say: "Without going the length of deeming this important enough to regulate the march of armies or the sailing of fleets or of proposing that the first appearance of these barometrical spiders in the spring should be announced by the sound of trumpet, I have reason to believe from my own observations that his statement is in the main accurate and that a very good 


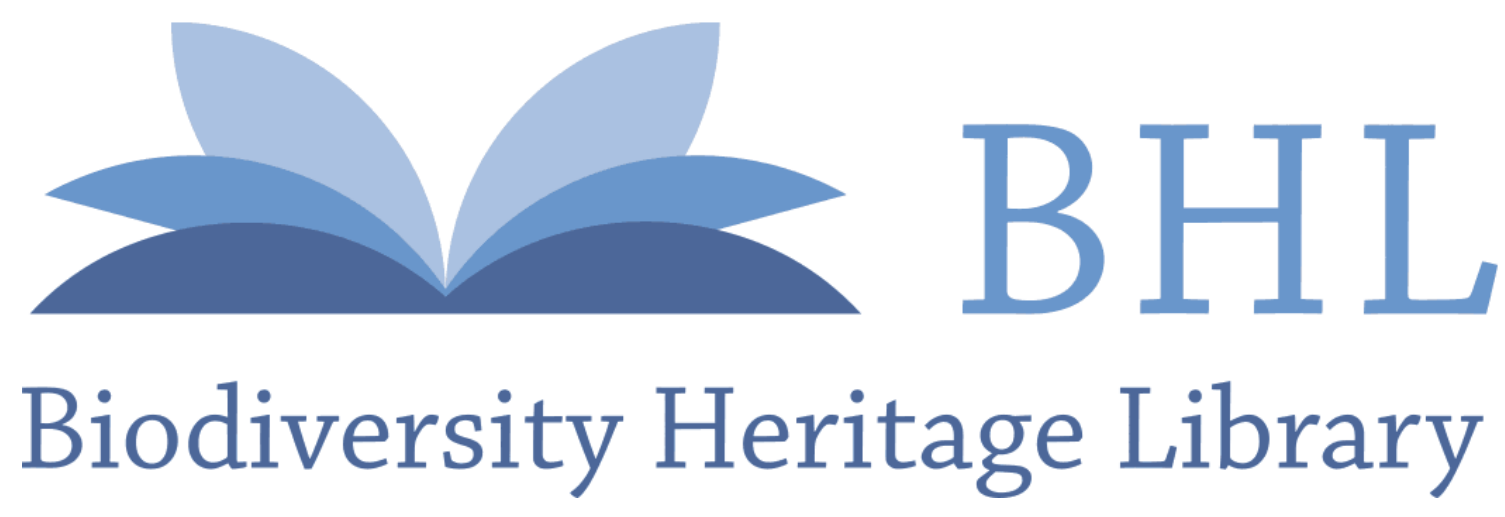

Davidson, W. M. 1915. "Occurrence of Eumerus (Syrphidae) in California." The Canadian entomologist 47, 134-135.

View This Item Online: https://www.biodiversitylibrary.org/item/22112

Permalink: https://www.biodiversitylibrary.org/partpdf/40340

\section{Holding Institution}

MBLWHOI Library

\section{Sponsored by}

MBLWHOI Library

\section{Copyright \& Reuse}

Copyright Status: NOT_IN_COPYRIGHT

This document was created from content at the Biodiversity Heritage Library, the world's largest open access digital library for biodiversity literature and archives. Visit BHL at https://www.biodiversitylibrary.org. 